\title{
Effect of Storage Container, Temperature and Duration on Germination of Leucaena leucocephala in Western Uttar Pradesh, India
}

\author{
Pankaj Lavania $^{1^{*}}$, Ashish Tiwari ${ }^{2}$ and Shailaja Punetha ${ }^{3}$ \\ ${ }^{1}$ RaniLaxmibai Central Agricultural University Jhansi, India \\ ${ }^{2}$ Department of forestry, Kumaun University, Nanital, Uttarakhand, India \\ ${ }^{3}$ GBPNIHE, Kosi-Katarmal, Almora, Uttarakhand, India \\ *Corresponding author
}

\section{Keywords}

Leucaena

leucocephala

Germination, Seed

germination,

Storage temperature and Container

Article Info

\section{Accepted:}

04 October 2020

Available Online:

10 November 2020

\section{A B S T R A C T}

Leucaena leucocephala (L.) commonly known as su-babul is a multipurpose nitrogen fixing, evergreen small tree of tropical and sub-tropical region, having high quality animal feed (pod), fodder, fuel wood, charcoal, pulp wood as well as contributing to soil stabilization and improvement through nitrogen fixation. Its leaves are uses as fodder, mulch and green manure. A problem is that pasture seeds are actually stored for a long period prior to accessibility to farmers especially in rural communities, because of inadequate communication facilities and the lack of extension services. Legume seeds generally lose viability in prolonged storage and also having the problem like as insect attacks, its seeds get damaged during storage in ordinary conditions. Hence, the present study was carried out to study the effect of storage period, containers and temperature on seed germination in laboratory and nursery condition. The seeds were stored up to 600 days in different containers at different temperature viz. poly bag at room temperature 15$40^{\circ} \mathrm{C}\left(\mathrm{B}_{1} \mathrm{~T}_{1}\right)$, poly bag at BOD $25^{\circ} \mathrm{C}\left(\mathrm{B}_{1} \mathrm{~T}_{2}\right)$, polybag at refrigerator $5^{\circ} \mathrm{C}\left(\mathrm{B}_{1} \mathrm{~T}_{3}\right)$, paper bag at room temperature $15-40^{\circ} \mathrm{C}\left(\mathrm{B}_{2} \mathrm{~T}_{1}\right)$, paper bag at BOD $25^{\circ} \mathrm{C}\left(\mathrm{B}_{2} \mathrm{~T}_{2}\right)$, paper bagrefrigerator $5{ }^{0} \mathrm{C}\left(\mathrm{B}_{2} \mathrm{~T}_{3}\right)$, cloth bag at room temperature $15-40{ }^{\circ} \mathrm{C}\left(\mathrm{B}_{3} \mathrm{~T}_{1}\right)$, cloth bag at BOD $25{ }^{0} \mathrm{C}\left(\mathrm{B}_{3} \mathrm{~T}_{2}-\right)$ and cloth bag- refrigerator $5{ }^{\circ} \mathrm{C}\left(\mathrm{B}_{3} \mathrm{~T}_{3}\right)$. The results revealed that seeds stored for 15 days in poly bag at refrigerator $5^{\circ} \mathrm{C}\left(\mathrm{B}_{1} \mathrm{~T}_{3}\right)$ recorded the maximum germination of in laboratory conditions which was at par with the germination observed in the seeds stored in cloth bag at refrigerator $5^{\circ} \mathrm{C}\left(\mathrm{B}_{3} \mathrm{~T}_{3}\right)$. Similar trend of seed germination was recorded when seeds were sown in the nursery conditions. The seed germination decreased with advancement of storage period in all the storage treatments. However, after 600 days of storage period, the maximum seed germination percent $(23.4 \pm 0.82)$ was recorded in $\mathrm{B}_{1} \mathrm{~T}_{3}$ which is at par with $\mathrm{B}_{3} \mathrm{~T}_{3}$ in Laboratory condition. Similar trend of seed germination was maximum in $B_{1} T_{3}$ which is at par with $B_{3} T_{3}$ in nursery condition.

\section{Introduction}

Leucaena leucocephala (Lam.) belongs to family Momosoideae, is a multi-purpose, medium-sized, almost evergreen tree with feathery foliage. It is commonly known as Subabul or kubabul and is found in tropical and subtropical countries. It is indigenous to 
Mexico, and EI Salvador and grow in in many Oceanic states like Philippine, Indonesia, Malaysia Hawaii, Fijii and India for various purpose such as soil conservation, to meet the growing demand of fuel, fodder and fertilizers. In India, It was tried in the last centuary in Andrapradesh Karnataka, Tamilnadu and Himachal pradesh and also in Uttarpradesh (Lohini, 1979). It can grow on a wide variety of soils and climatic conditions, from sea level to an altitude of $500 \mathrm{~m}$. It can tolerate high temperature $\left(>45^{\circ} \mathrm{C}\right)$ and drought conditions, but adequate moisture is needed for its good growth. It is an $\mathrm{N}$-fixing legume tree.

The species is capable of tolerating large variations in rainfall temperature, wind drought and topography (NAS, 1977). In poor soil area it contribute to soil stabilization and improvement in soil through nitrogen fixation $100-200 \mathrm{Kg} / \mathrm{ha}$ (NAS-1984) and also provide high quality animal feed (pod), fodder, fuel wood, charcoal, and pulp. Its leaves are also uses as fodder, mulch and green manure. This speciesis relished by livestock as well as wildlife and as such it is promising forage crop for tropics and subtropics. Forage production from Cunningham variety planted in a single rows along the farm road at Jhansi at a spacing of $2 \mathrm{~m}$ was 0.75 and $1.94 \mathrm{~kg} /$ tree at 3 and 4 year of age respectively (Parkash and Hocking, 1988.) It is suitable for making unbleached and bleached kraft pulp for wrapping and writing papers(Singh et al 1986).

To raise large scale seedlings for plantations, a huge quantity of Leucaena leucocephala seed is required and a full grown tree of can produce 5000-6000 pods in a good fruiting season, each with usually between 15-30 seeds. Its seeds also exhibit seed dormancy due to the presence of hard seed coat. In ordinary storage conditions, This specie is under several anthropogenic pressures and their regeneration has been severely affected as trees are lopped for fodder and also due to insect attacks, its seeds get damaged during storage in ordinary condition.

The information on effect of seed storage on germination of subabul is scarce. Keeping in view the importance of the Leucaena leucocephala the present study was carried out to see the effect of storage temperature, period and container on seed germination.

\section{Materials and Methods}

The study area (Western Uttar Pradesh) lies between $27^{\circ} 10^{\prime} \mathrm{N}$ to $26^{\circ} 04 \mathrm{~N}^{\prime}$ latitude and $78^{\circ}$ 02' $\mathrm{E}$ to $79^{0} 7^{\prime} \mathrm{E}$ longitude between elevation 165 and $179.8 \mathrm{~m}$ above m.s.l. The seeds were collected from Agra and adjoining areas viz., Mathura and Hathrus. The seeds collected from different sites were mixed together and used for study.

Before storage of seed in different containers viz., poly bag, paper bag cloth bag at different temperature i.e. room temperature $\left(15-40{ }^{\circ} \mathrm{C}\right)$, BOD $\left(25{ }^{0} \mathrm{C}\right)$ and refrigerator $\left(3-5{ }^{0} \mathrm{C}\right)$, the seeds were treated with Thiram 75 DS and Leaf of Neem. The detail of the treatments is given as. Poly bag at room temperature 15$40^{\circ} \mathrm{C}\left(\mathrm{B}_{1} \mathrm{~T}_{1}\right)$, Poly bag at $\operatorname{BOD}\left(25^{\circ} \mathrm{C}\left(\mathrm{B}_{1}\right.\right.$ $\mathrm{T}_{2)}$, Poly bag at refrigerator $5{ }^{0} \mathrm{C}\left(\mathrm{B}_{1} \mathrm{~T}_{3)}\right.$, Paper bag at room temperature $15-40{ }^{\circ} \mathrm{C}\left(\mathrm{B}_{2}\right.$ $\mathrm{T}_{1}$, Paper bag at BOD $25{ }^{\circ} \mathrm{C}\left(\mathrm{B}_{2} \mathrm{~T}_{2}\right)$, Paper bag-refrigerator $5{ }^{0} \mathrm{C}\left(\mathrm{B}_{2} \mathrm{~T}_{3}\right)$, Cloth bag at room temperature $15-40{ }^{0} \mathrm{C}\left(\mathrm{B}_{3} \mathrm{~T}_{1}\right)$, Cloth bag at BOD $25{ }^{0} \mathrm{C}\left(\mathrm{B}_{3} \mathrm{~T}_{2}-\right)$ and Cloth bagRefrigerator $5{ }^{0} \mathrm{C}\left(\mathrm{B}_{3} \mathrm{~T}_{3}\right)$.

After 15 days of seed collection, they were tested to know the germination percent and thereafter the germination tests were conducted in lab and nursery condition at the interval of 60 days up to 600 days.

For lab study, three replication of 50 seeds, each was used. The germination was carried out in petri dishes. Germination percent was 
counted when visible radicle emerged. Under Nursery conditions, three replications of 100 seeds each from different storage treatment were sown in line in nursery beds. After every 15 days seed sowing, germination (\%) was counted by the following formula:

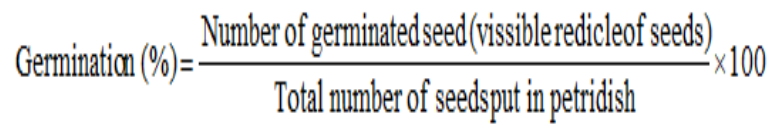

Standard error was calculated by using the given formula (Chandel, 1998). Standard deviation was calculated by using the given formula (Chandel, 1998).

\section{Results and Discussion}

\section{Seed germination under laboratory conditions}

The data presented in Table 1, showed that maximum germination $(54.8 \%)$ in laboratory conditions was recorded when seeds were stored in poly bag at refrigerator $5^{0} \mathrm{C}\left(\mathrm{B}_{1} \mathrm{~T}_{3}\right)$ and sown after 15 days of collection.

Although, the seeds stored in cloth bag at refrigerator $5{ }^{0} \mathrm{C}\left(\mathrm{B}_{3} \mathrm{~T}_{3}\right)$ also registered 54.4 $\%$ germination which was at par with $\mathrm{B}_{1} \mathrm{~T}_{3}$. The seeds were stored up to 600 days and germination tests were conducted at the interval of 60 days.

The findings of these germination tests revealed that the germination percent declined with the advancement of storage period in all the treatments.

After 300 days of storage in treatment $\mathrm{B}_{1} \mathrm{~T}_{3}$, the germination decreased up to $23.4 \%$ which further declined to $22.2 \%\left(\mathrm{~B}_{3} \mathrm{~T}_{3}\right)$ after 600 days of storage. Although this germination was maximum in comparison to all other storage treatments.
These results were in conformity with the findings, Sharma (1980) who reported the maximum germination in fresh seeds of Moringa oleifera and observed that with the progressive storage period the germination percent declined considerably.

This study have also supported by observation, made in Shorea robusta seeds (Purohit, Sharma and Thapliyal (1982), in Toona ciliata (Nautiyaland Thapliyal, 1993) in Fagussy lytica seed (Lepper et al., 1994), in Populus ciliata seeds (Shah et al.1995), in Azadirachta indica seed Singh et al. 1997, in Dendrocalamus brandisii seeds (Boonarutee and Samboon 1995) and Greviao ptiva seeds (Nayal, 2000).

\section{Seed germination under nursery conditions}

Almost similar trend of seed germination was recorded when seeds stored in different containers and temperatures were sown in the nursery (Table 2). The maximum germination $(53.3 \%)$ was recorded when seeds were sown after 15 days of harvesting in nursery conditions $\left(\mathrm{B}_{3} \mathrm{~T}_{3}\right)$. The seeds stored in poly bag at refrigerator $5{ }^{0} \mathrm{C}\left(\mathrm{B}_{1} \mathrm{~T}_{3}\right)$ shown almost equal $(52.2 \%)$ germination in the same treatment.

The decline in germination percent with advancement of storage period was also recorded in nursery condition, but the lesser germination was recorded in nursery as compared to laboratory conditions.

After 300 days of storage period only $53.3 \%$ of seed germinated which further declined to $17.4 \%$ after 600 days of storage period. The seed stored in paper bag at refrigerator $5{ }^{0} \mathrm{C}$ $\left(\mathrm{B}_{2} \mathrm{~T}_{3}\right)$ also gave almost same germination $(16.8 \%)$ after 600 days storage period. 
Table.1 Germination percent in Leucaena leucocephala under different storage treatments in Laboratory

\begin{tabular}{|c|c|c|c|c|c|c|c|c|c|c|}
\hline \multirow[t]{2}{*}{ S.N. } & \multicolumn{10}{|c|}{ Germination $(\%)$ in storage treatments } \\
\hline & Storage Days & $\mathrm{B}_{1} \mathrm{~T}_{1}$ & $\mathrm{~B}_{1} \mathrm{~T}_{2}$ & $\mathrm{~B}_{1} \mathrm{~T}_{3}$ & $\mathrm{~B}_{2} \mathrm{~T}_{1}$ & $\mathrm{~B}_{2} \mathrm{~T}_{2}$ & $\mathrm{~B}_{2} \mathrm{~T}_{3}$ & $\mathrm{~B}_{3} \mathrm{~T}_{1}$ & $\mathrm{~B}_{3} \mathrm{~T}_{2}$ & $\mathbf{B}_{\mathbf{3}} \mathbf{T}_{\mathbf{3}}$ \\
\hline 1 & 15 & $48.0 \pm 0.60$ & $53.2 \pm 1.54$ & $54.8 \pm 1.75$ & $45.2 \pm 0.61$ & $50.5 \pm 1.62$ & $48.1 \pm 0.55$ & $43.2 \pm 0.76$ & $47.2 \pm 0.61$ & $54.5 \pm 0.68$ \\
\hline 2 & 60 & $46.6 \pm 1.00$ & $49.6 \pm 1.35$ & $53.1 \pm 0.71$ & $41.7 \pm 1.07$ & $46.8 \pm 0.53$ & $43.2 \pm 0.98$ & $41.4 \pm 0.74$ & $45.2 \pm 1.17$ & $51.6 \pm 1.41$ \\
\hline 3 & 120 & $42.4 \pm 0.98$ & $45.6 \pm 6.27$ & $47.6 \pm 0.49$ & $35.8 \pm 0.45$ & $45.0 \pm 0.84$ & $38.1 \pm 1.50$ & $34.3 \pm 0.56$ & $40.2 \pm 1.38$ & $45.7 \pm 0.90$ \\
\hline 4 & 180 & $36.6 \pm 1.00$ & $42.1 \pm 0.89$ & $45.8 \pm 0.25$ & $34.5 \pm 1.25$ & $43.4 \pm 2.46$ & $36.7 \pm 0.55$ & $33.4 \pm 0.57$ & $39.3 \pm 1.03$ & 43.1 \pm 1.17 \\
\hline 5 & 240 & $33.6 \pm 0.78$ & $39.6 \pm 1.32$ & $44.0 \pm 0.41$ & $33.2 \pm 1.88$ & $40.7 \pm 0.99$ & $35.0 \pm 0.41$ & $30.1 \pm 1.67$ & $36.2 \pm 0.10$ & $41.3 \pm 0.64$ \\
\hline 6 & 300 & $30.7 \pm 1.70$ & $31.9 \pm 1.10$ & $40.9 \pm 0.35$ & $30.6 \pm 1.17$ & $35.2 \pm 1.25$ & $34.1 \pm 1.00$ & $26.1 \pm 1.38$ & $34.0 \pm 0.91$ & $36.2 \pm 0.96$ \\
\hline 7 & 360 & $25.4 \pm 0.51$ & $26.1 \pm 0.53$ & $29.1 \pm 1.05$ & $27.8 \pm 1.51$ & $27.5 \pm 1.68$ & $25.7 \pm 1.72$ & $24.3 \pm 1.99$ & $26.2 \pm 1.76$ & $30.1 \pm 1.79$ \\
\hline 8 & 420 & $25.0 \pm 0.76$ & $24.5 \pm 1.24$ & $28.6 \pm 1.27$ & $26.5 \pm 0.75$ & $24.3 \pm 1.53$ & $23.3 \pm 1.19$ & $23.1 \pm 1.69$ & $24.8 \pm 0.99$ & $27.3 \pm 0.84$ \\
\hline 9 & 480 & $24.1 \pm 1.08$ & $23.8 \pm 0.30$ & $26.7 \pm 0.89$ & $24.2 \pm 0.93$ & $23.7 \pm 1.37$ & $22.7 \pm 2.01$ & $22.4 \pm 2.01$ & $23.3 \pm 1.15$ & $25.2 \pm 3.87$ \\
\hline 10 & 540 & $23.2 \pm 1.77$ & $22.1 \pm 0.46$ & $25.1 \pm 0.38$ & $21.2 \pm 1.16$ & $23.2 \pm 0.81$ & $23.1 \pm 0.57$ & $21.2 \pm 1.12$ & $20.2 \pm 0.88$ & $23.2 \pm 1.20$ \\
\hline 11 & 600 & $15.01 \pm 2.13$ & $21.3 \pm 1.06$ & $23.4 \pm 0.82$ & $18.0 \pm 2.24$ & $19.1 \pm 0.80$ & $21.8 \pm 0.56$ & $19.0 \pm 1.39$ & $19.5 \pm 0.64$ & $22.2 \pm 1.41$ \\
\hline
\end{tabular}

Table.2 Germination loss in Leucaena leucocephala under different storage treatments in Nursery

\begin{tabular}{|c|c|c|c|c|c|c|c|c|c|c|c|}
\hline \multirow[t]{2}{*}{ S.N. } & \multirow{2}{*}{\multicolumn{2}{|c|}{ Storage Day }} & \multicolumn{9}{|c|}{ Germination $(\%)$ in storage treatments } \\
\hline & & & $\mathrm{B}_{1} \mathrm{~T}_{1}$ & $\mathrm{~B}_{1} \mathrm{~T}_{2}$ & $\mathrm{~B}_{1} \mathrm{~T}_{3}$ & $\mathrm{~B}_{2} \mathrm{~T}_{1}$ & $\mathrm{~B}_{2} \mathrm{~T}_{2}$ & $\mathrm{~B}_{2} \mathrm{~T}_{3}$ & $\mathrm{~B}_{3} \mathrm{~T}_{1}$ & $\mathrm{~B}_{3} \mathrm{~T}_{2}$ & $\mathbf{B}_{\mathbf{3}} \mathbf{T}_{\mathbf{3}}$ \\
\hline 1 & $\mathrm{D}_{1}$ & 15 & $43.8+0.47$ & $48.7+0.75$ & $52.2+1.03$ & $40.2+0.58$ & $45.5+0.71$ & $43.4+1.24$ & $39.2+2.14$ & $44.4+0.88$ & $53.1+1.01$ \\
\hline 2 & $\mathrm{D}_{4}$ & 60 & $40.7 \pm 0.63$ & $44.7 \pm 1.65$ & $47.9 \pm 1.83$ & $38.1 \pm 0.21$ & $42.8 \pm 0.37$ & $39.2 \pm 0.96$ & $37.5 \pm 1.68$ & $40.1 \pm 0.47$ & $45.3 \pm 1.03$ \\
\hline 3 & $\mathrm{D}_{8}$ & 120 & $32.1 \pm 0.68$ & $39.5 \pm 1.00$ & $40.1 \pm 0.44$ & $27.5 \pm 1.75$ & $35.2 \pm 0.77$ & $33.0 \pm 0.62$ & $26.4 \pm 0.50$ & $34.0 \pm 1.42$ & $36.7 \pm 0.50$ \\
\hline 4 & $\mathrm{D}_{10}$ & 180 & $31.0 \pm 0.88$ & $36.1 \pm 1.12$ & $38.1 \pm 0.69$ & $26.0 \pm 0.22$ & $33.5 \pm 0.55$ & $31.9 \pm 0.64$ & $24.7 \pm 0.70$ & $31.2 \pm 0.95$ & $34.3 \pm 1.31$ \\
\hline 5 & $\mathrm{D}_{12}$ & 240 & $22.1 \pm 0.68$ & $31.4 \pm 0.57$ & $34.9 \pm 1.92$ & $24.7 \pm 0.17$ & $26.3 \pm 0.99$ & $29.5 \pm 2.27$ & $21.9 \pm 0.41$ & $28.5 \pm 0.44$ & $27.4 \pm 1.04$ \\
\hline 6 & $\mathrm{D}_{14}$ & 300 & $21.0 \pm 1.28$ & $27.5 \pm 1.83$ & $27.5 \pm 0.55$ & $22.7 \pm 0.55$ & $23.0 \pm 0.57$ & $26.1 \pm 0.49$ & $21.2 \pm 0.46$ & $24.2 \pm 1.72$ & $26.5 \pm 0.95$ \\
\hline 7 & $\mathrm{D}_{16}$ & 360 & $20.5 \pm 0.45$ & $23.5 \pm 0.98$ & $26.1 \pm 0.93$ & $21.2 \pm 0.35$ & $21.8 \pm 1.21$ & $23.8+0.94$ & $20.1 \pm 2.41$ & $23.0 \pm 0.53$ & $24.9 \pm 0.72$ \\
\hline 8 & $\mathrm{D}_{17}$ & 420 & $20.2+1.15$ & $22.01 \pm 0.25$ & $24.3 \pm 1.01$ & $21.0+0.95$ & $21.2 \pm 0.44$ & $23.4+1.10$ & $20.1 \pm 0.57$ & $22.3+0.70$ & $24.3 \pm 0.66$ \\
\hline 9 & $\mathrm{D}_{18}$ & 480 & $20.2 \pm 1.06$ & $21.8 \pm 1.04$ & $22.2 \pm 0.90$ & $19.9 \pm 0.49$ & $17.3 \pm 0.70$ & $22.9 \pm 1.39$ & $17.3 \pm 1.15$ & $18.5 \pm 3.37$ & $23.0 \pm 1.57$ \\
\hline 10 & $\mathrm{D}_{19}$ & 540 & $19.1 \pm 0.69$ & $18.3 \pm 1.30$ & $20.2 \pm 0.85$ & $19.2 \pm 0.61$ & $15.8 \pm 1.39$ & $22.6 \pm 0.94$ & $15.7 \pm 1.04$ & $17.6 \pm 1.08$ & $19.5 \pm 1.37$ \\
\hline 11 & $D_{20}$ & 600 & $14.1 \pm 0.81$ & $14.3 \pm 0.68$ & $17.4 \pm 1.33$ & $14.1 \pm 1.09$ & $13.1 \pm 0.72$ & $16.8 \pm 0.43$ & $13.5 \pm 0.73$ & $12.7 \pm 0.91$ & $14.5 \pm 0.36$ \\
\hline
\end{tabular}


From these results it has been observed that in all storage conditions the germination decreased with the advancement of storage period. However, the germination loss was minimum in $\mathrm{B}_{1} \mathrm{~T}_{3}$ and after 600 days $17.4 \%$ germination was recorded. Next best storage treatment was $\mathrm{B}_{2} \mathrm{~T}_{3}$, In which germination was recorded. Its seeds are heavily attacked by insects; we have required most appropriate container and temperature for long storage. Temperature substratum plays a very significant role during the process of seed germination. Seed of some species germinate better at constant temperature while other alternate temperature (Anon 1966, Bonner 1972, Kumar and Gopal 1974). This present study was also supported by Abdelgabar et al., 2014 in Acacia senegal, Acacia mellifera and Acacia laeta, Joshi 2002 in Dalbergia sissoo, Thapiyal et al., 1991 in Bambusa tulda, Arjuman et al., 1966 in Erythian astrieta, Aswathanarayan et al., (1996) in Prosopis juliflora, Dalbergia sissoo, and Casuriana equisetifolia. Sharma et al., (2002) in Albizialebbek.

The present study may be concluded that the seeds of Leucaena leucocephala can be stored for longer period either in polybag or cloth bag at $5^{\circ} \mathrm{C}$ for long term storage to get maximum germination.

\section{References}

Abdelgabar S. et al., Effect of storage types on seed moisture content and germination of Acacia senegal, Acacia mellifera and Acacia laeta, Jour. of Nat. Resour. \& Environ. Stu., 2014; $2.2,36-41$

Anon. International rules for seed testing. Proc. Int. seed test Assoc, 1966, 31(1).

Arjuman MC, Tamil Selvi M, Lakshmanan KK. Seed collection, Storage and Germination in Erythiana stricta. Madras Agricultural Journal. 1996;
83:4:241-244.

Aswathanarayan SC, Mahadevappa M, Rangnathaiah KG, Kalappa VP, Reddy Yan. Seed viability and microflora of forest trees: Indian Journal of forestry. 1996; 19:4, 326329.

Boonarutee P, Somboon K. Effect of temperature and seed moisture content on the storage of Dendrocalamus brandisii. Seeds. In.: Tropical Tree Seed Research (ed Turn bull. J.M.) zICIAR Proceeding, 1990; 28:86-88.

Chandel SRS. A hand book of Agriculture statistic, Edn. 1998, Achal Prakashan Mandir, Kanpur, 1998, A-89-99.

Joshi G. Physiological investigation on germination and viability of Dalbergia sissoo, Roxb. Seed for ex-situ germplasm conservation. Ph.D. Thsis, Forest research Institute, Deemed University, Dehradun, 2002.

Kumar A, Gopal M. A note on temperature sensitivity of red sanders (Pterocarpus Santalinus. L.f.) Seed for germination. 17th Int. Seed Test. Assoc. Cong. Warsaw, 1974.

Lepper P, Pitzen H, Debus R, Heydar J Schmitt. Influence of selected storage condition on viability and metabolism of beech nut. 1994; 113(5): 302-318.

National Academy of Science. Leucaena: Promising forage and tree crop for tropics. National Academy of Science. Washington, D.C.1977 115.

Nautiyal AR, Thapliyal P. On cause of loss of seed viability in Toona ciliate Rem. Ind. J. For. 1993; 16:167- 169.

NayalJS. Evaluation of various storage technique to prolong the seedling viability and vigour of Azadirachta indica and Grewia optiwa, Ph.D. thesis FRI, Dehradun, Deemed University Dehradun, 2000.

Parkash, Ram and Hocking Darake 1988. Some favourite trees for fuel and 
fodder, society for promotion of wasteland development, Sucheta Bhawan Annexe, 11-A Vishnu Digamber Marg, New Delhi. Pp. 2128.

Purohit AN, Sharma MM, Thapliyal RC. Effect of Storage temperature on the viability of Sal (Shorea robusta) and tolura (Shorea talura) seeds For. Sci. 1982; 28(3): 526-530.

Shah VK, Singh Virendra, Singh V. Effect of temperature \& storage on seed germination in Populus ciliata Wall ex-royal in Garwal Himalaya. Indian Forester. 1995; 12(4):273-275.

Sharma Archana, Agrawal Sunil. Effect of different method of seed collection \& storage on seed quality of Albizia lebbek (L.). Vaniki Sandesh. 2002; 26(3):(3/4):1- 7.

Sharma, G.K. Propagation techniques of
Moringa oleifera Lam. M.Sc. Thesis, Dr. Y.S. Parmar, University of Horticulture and Forestry, Nauni, Solan (H.P.). 1980.

Sharma Archana, Agrawal Sunil. Effect of different method of seed collection \& storage on seed quality of Albizia lebbek (L.). VanikiSandesh. 2002; 26(3):3/4):1- 7 .

Singh BG, Mahadevan NP, Shanthi K, Manimuthu L, Geetha L. Effect of moisture content in viability land storability of Azadirachta indica, 1997. Singh et al 1986).

Thapliyal RC, Sood OP, Rawat MMS. Effect of moisture content and storage temperature on viability of Bambusa tulda seed. Int Tree Crops. Jour. 1991; 7:67-9.

\section{How to cite this article:}

Pankaj Lavania, Ashish Tiwari and Shailaja Punetha. 2020. Effect of Storage Container, Temperature and Duration on Germination of Leucaena leucocephala in Western Uttar Pradesh, India. Int.J.Curr.Microbiol.App.Sci. 9(11): 792-797. doi: https://doi.org/10.20546/ijcmas.2020.911.096 